\title{
Closure of Large Oroantral Fistula with Resorbable Collagen Membrane - Case Report
}

\author{
Aleksa Marković, Snježana Čolić, Radojica Dražić, Ljiljana Stojčev, Bojan Gačić \\ Clinic of Oral Surgery, School of Dentistry, University of Belgrade, Belgrade, Serbia
}

\begin{abstract}
Summary
Oroantral fistula is pathologic communication between oral cavity and maxillary sinus, usually localised between antrum and buccal vestibulum. Persisting OAF always causes chronic maxillary sinusitis.A technique for closure of a large oroantral fistula with resorbable collagen membrane is described.
\end{abstract}

Keywords: oroantral communication; oroantral fistula; collagen membrane

\section{INTRODUCTION}

Oroantral fistula (OAF) is pathologic communication between oral cavity and maxillary sinus, usually localised between antrum and buccal vestibulum. Persisting OAF always causes chronic maxillary sinusitis $[1,2]$.

To eliminate OAF, various surgical procedures such as local and distant flaps, use of bone grafts and alloplastic materials are described [3-9]. Titanium and gold foil as alloplastic materials could also be used for closure [10]. Gelatin film, and non-resorbable polytetrafluoroetylen (ePTFE) membrane were the first guided tissue regeneration (GTR) technique described for closure of OAC [11]. Bioabsorbable root analogue for closure of OAF has been reported recently [12]. Collagen membranes used in GTR techniques, separates soft tissues from bone and neighbouring periodontal tissues, enhancing osseous healing [13].

We present a case of closure of a large OAF with Bio-Gide ${ }^{\varpi}$ collagen membrane.

\section{CASE REPORT}

A 32-year-old male patient was reffered to the Clinic of Oral Surgery, School of Dentistry, University of Belgrade. Patient's history revealed removal of upper right first molar and patient reported pain 14 days after tooth removal. On clinical examination OAF was present, and after radiographic examination chronic right maxillary sinusitis was diagnosed (Figures 1 and 2). Preoperatively, the affected sinus was irrigated through the fistula with physiological saline solution and Gentamicin solution ( $80 \mathrm{mg})$, daily for 14 days to reduce infection (Figure 3). There was not purulent discharge and natural ostium was patent.

Immediately before the surgical procedure, the patient received amoxicillin and clavulanic acid (Amoksiklav), $1 \mathrm{~g}$ twice daily for 7 days. Modified Caldwell-Luc operation with oral antrostomy was performed under local anaesthesia with Lidocain an epinephrine $2 \%$. A buccal flap was created and sinus was explored through canine

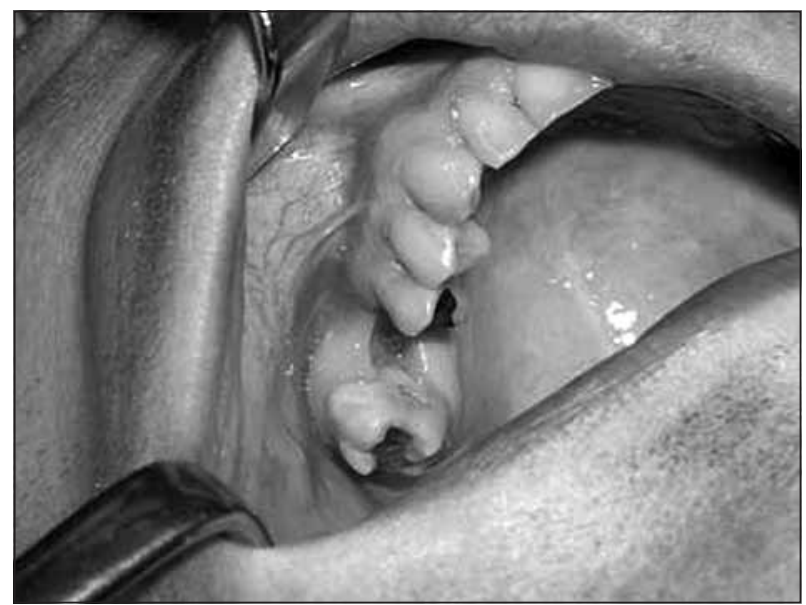

Figure 1. Oroantral fistula localised in the region of the first upper right molar

Slika 1. Oroantralna fistula lokalizovana u regiji prvog gornjeg desnog molara

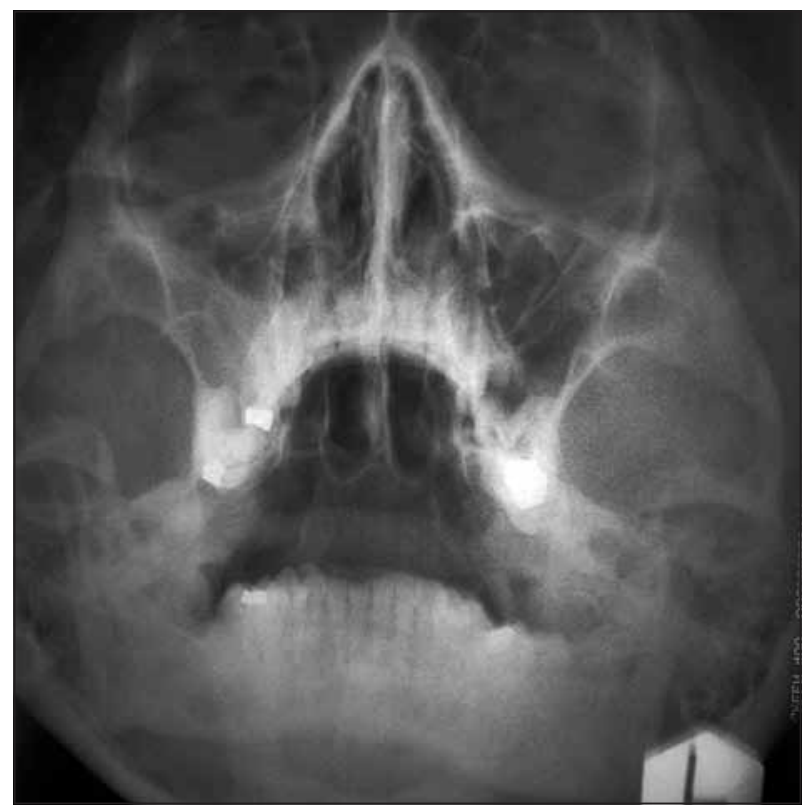

Figure 2. On PA radiogram a soft tissue shadow in the right maxillary sinus indicating chronic sinusitis

Slika 2. Na PA rendgenskom snimku uočava se senka mekog tkiva u desnom maksilarnom sinusu koja ukazuje na hronični sinuzitis 


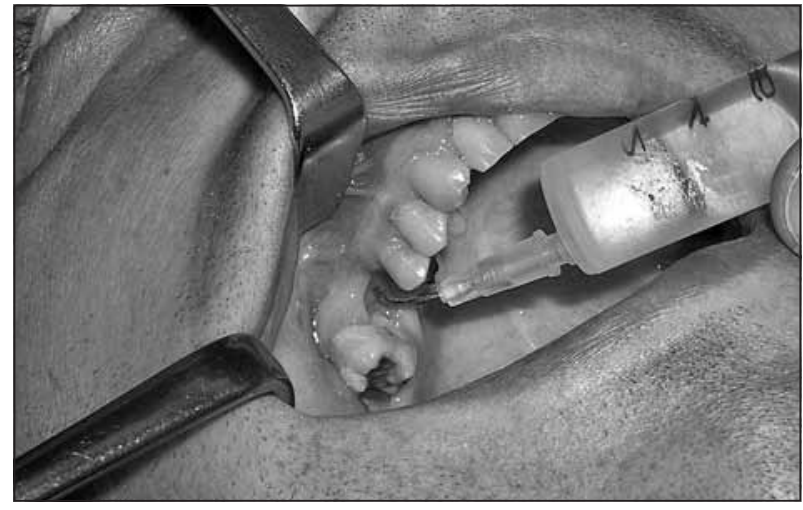

Figure 3. Rinsing of maxillary sinus with physiologic saline Slika 3. Ispiranje maksilarnog sinusa fiziološkim rastvorom natrijum-hlorida

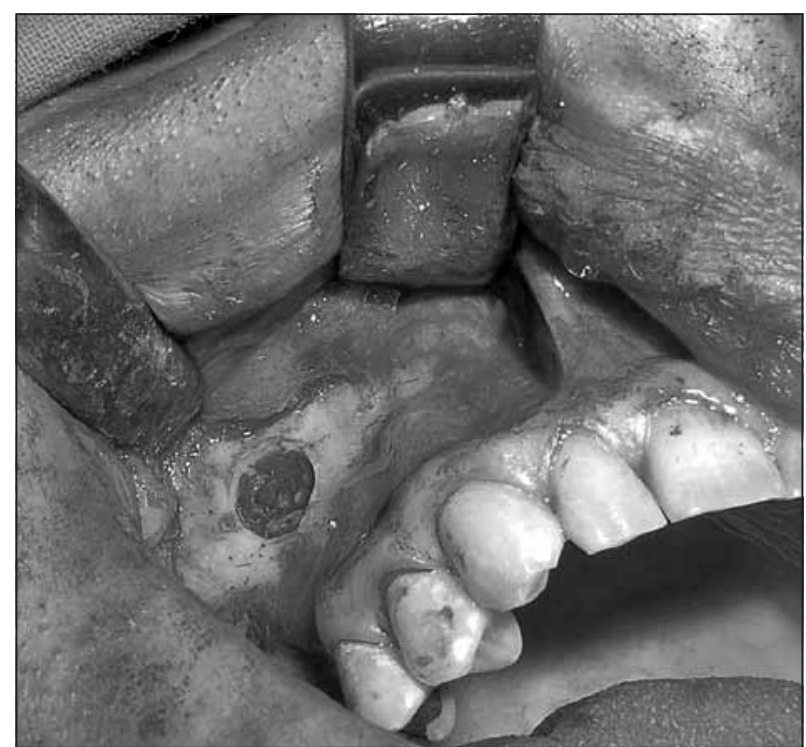

Figure 4. Explored maxillary sinus through the canine fossa approach

Slika 4. Otvoreni maksilarni sinus preko canine fossa

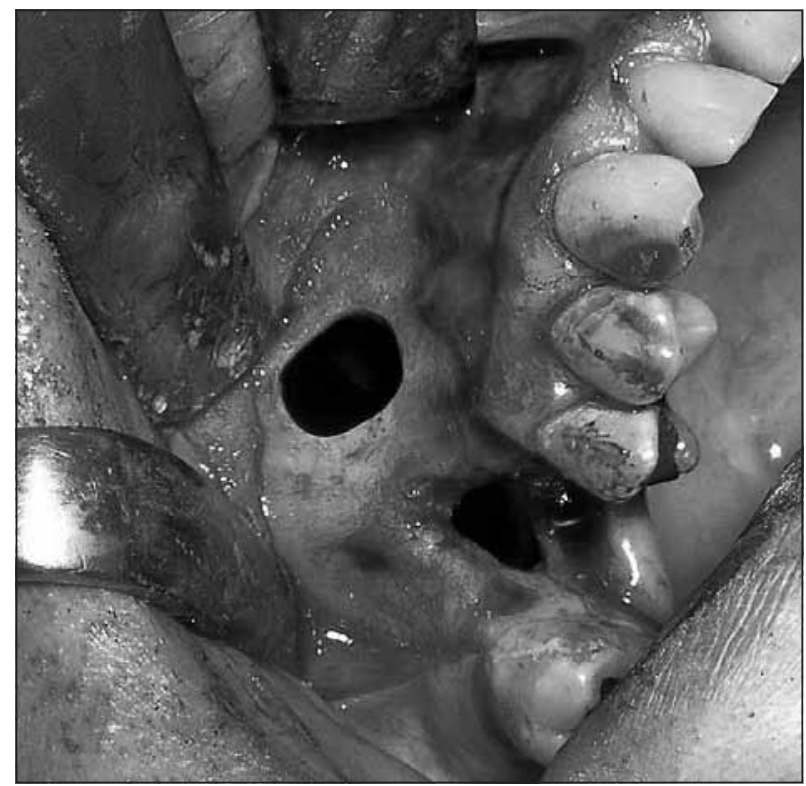

Figure 5. Large bone defect and denuded mesial root of the second upper molar

Slika 5. Veliko oštećenje kosti i ogoljeni mezijalni koren drugog gornjeg molara

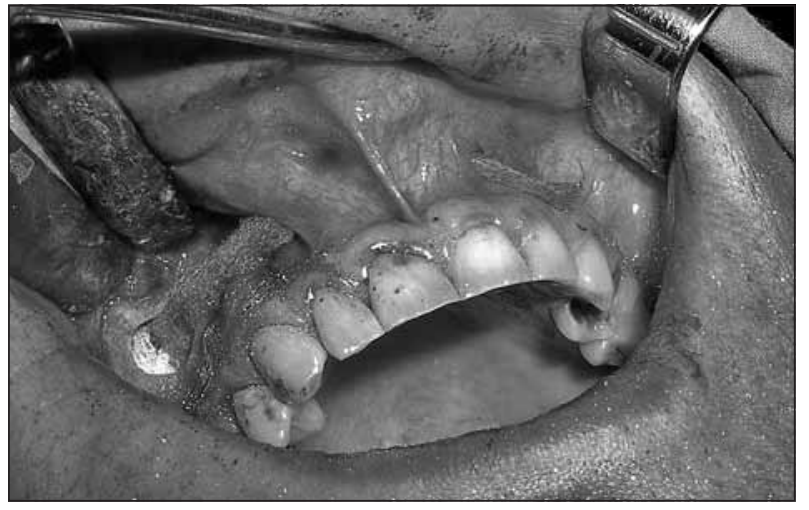

Figure 6. Vestibular drainage with gauze through the submucosal tunnel

Slika 6. Vestibularna drenaža gazom kroz submukozni tunel

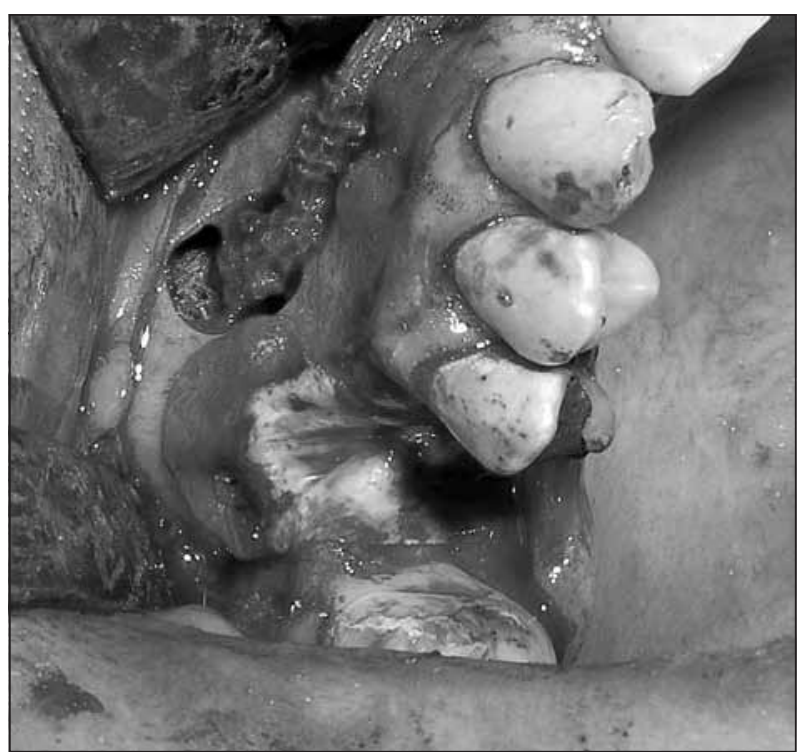

Figure 7. Resorbable membrane placed over bone defect fixed with resorbable pins

Slika 7. Resorptivna membrana postavljena preko oštećenja kosti fiksirana resorptivnim klinovima

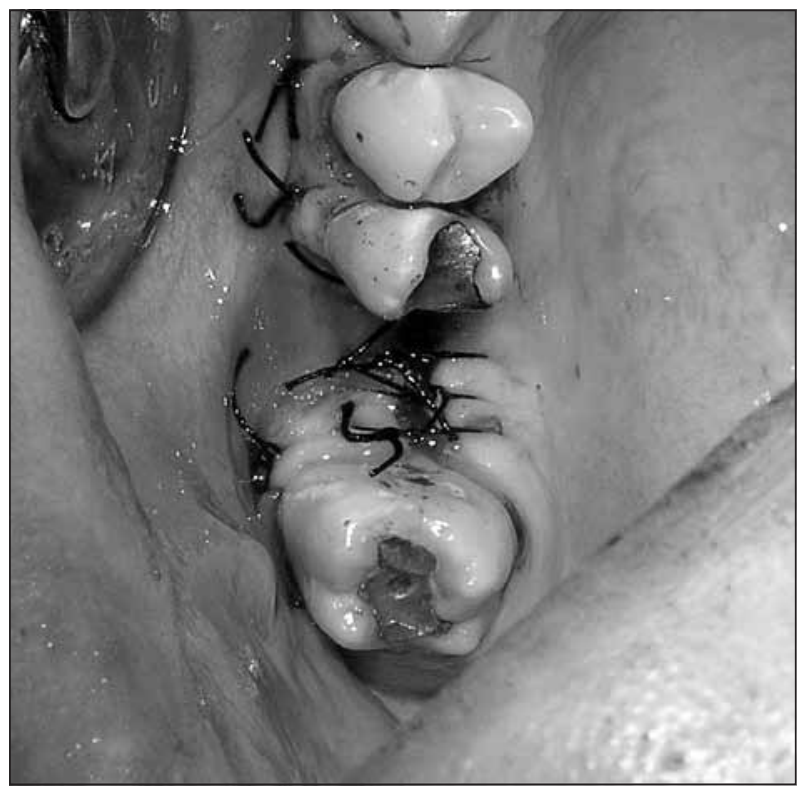

Figure 8. Buccal flap sutured to its original position and exposed membrane

Slika 8. Bukalni režanj zašiven na prvobitnu poziciju i izložena membrana 
fossa (Figure 4). After excision of fistulous tissue and curretage of extraction socket, $15 \times 20 \mathrm{~mm}$ bone defect, and denuded mesial root of the neighbouring tooth 27 revealed (Figure 5). Inflammed, degenerated and polipoid mucosa was removed and sinus cavity was packed with iodophor-gauze. Vestibular drainage with gauze was established through submucosal tunnel to the opposite side in the region of second incisor (Figure 6).

Resorbable collagen membrane (Bio-Gide ${ }^{\ominus}$, Geistlich, Wolhusen,Switzerland) was placed over bony defect, and its position secured with resorbable pins (Figure 7). Buccal flap was repositioned to its original position without incising the periosteum, and sutured with interrupted sutures (Silk 3-0). Membrane was exposed to the oral cavity $3 \mathrm{~mm}$

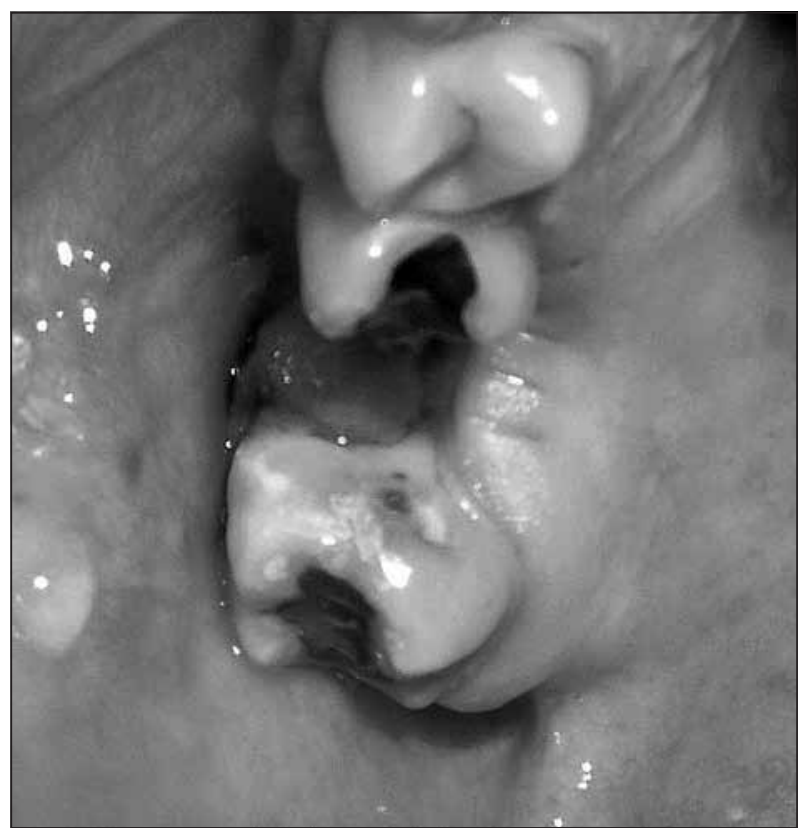

Figure 9. Reduced area of exposed membrane after one week Slika 9. Redukovana oblast izložene membrane posle jedne nedelje

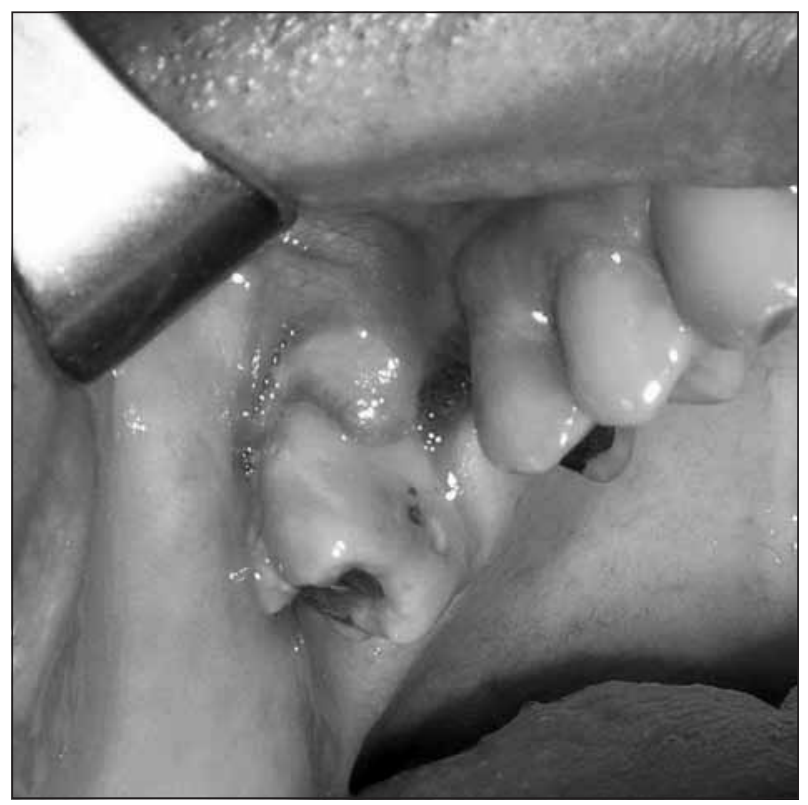

Figure 10. Complete coverage of membrane at the end of second week

Slika 10. Potpuno pokrivanje membrane na kraju druge nedelje in buco-palatal, and $10 \mathrm{~mm}$ in mesio-distal direction (Figure 8). After surgery patient was presccribed nasal decongestants and mouth wash with $0,12 \%$ chlorheksidine-digluconate, twice daily until the end of epithelisation. Gause was shortened on $2^{\text {nd }}$, and removed on $4^{\text {th }}$ day, while sutures were removed on $7^{\text {th }}$ day after surgery. Postoperative period was uneventfull.

Area of epithelisation was measured with the lenght of the parodontal probe until end of epithelisation.In the first week half of the exposed membrane was covered with epithelium (Figure 9). Complete coverage of membrane was noted on the end of second week (Figure 10). On the control radiographs 3, 6, and 24 months after surgery there were no changes in maxillary sinus mucosa, and ossification of subantral portion of the bone was evident.

\section{DISCUSSION}

Oroantral communication $(\mathrm{OAC})$ is common complication after upper molars extraction or in the cases of presence of periapical lesions, cysts, or tumors [14]. 50\% of untreated OACs induce inflammatory changes in maxillary sinus mucosa in first 48 hours, while $90 \%$ of them progress into maxillary sinusitis two weeks after OACs formation [15]. Small OACs less than $2 \mathrm{~mm}$ in diametar tends to heal spontaneously [16], if the sinus is free of inflammation, while larger ones require surgical intervention. OACs closure is mandatory in first 24 hours, contrary to that an OAF may develop as a consequence [17]. OAF in the region of periodontally involved neighboring teeth represent a problem for sucessfull healing of most soft tissue flaps.

Buccal, palatal or combined flaps are widely used for closure. Bucall flaps are the most frequenly used procedures, but flap overtension $[16,17]$, postoperative haematoma $[4,5,9]$ and reduction of buccal sulcus depth $[18$, 19] can compromise sucessful closure or complicate final prosthetic treatment. Moreover the loss of bone usually associated with OAF can sometimes lead to dehiscence, and relapse. Such bone defect covered with buccall flap only, heals by fibrous tissue, that makes implant placement impossible without another grafting surgery. Palatal flaps produce a denuded area that heals by secondary intention, and may be accompained by pain; and in addition healing of palatal defects is prolonged with possible scarring $[3,10,17]$.

In the cases of larger bony defect, closure of OAF with buccal fat pad has advantages in relation to buccal flaps, and does not interfere with the buccal sulcus depth. Risk of invagination of fat tissue, unpredictable secondary healing, infection, and necrosis, fibrosis, shrinkage, retraction and distortion can occur [3]. As in cases of buccal flaps there is no bony regeneration of bony defect.

Proctor [8] described in 1969 closure of OAF with iliac crest bone graft, indicated in very large defects is attractive technique for augmentation of subantral bone dimension and implant placement, but because of its morbidity its usage is limited. 
Monocortical chin grafts [6] could be used for closure of OAC, and in cases of moderately large bony defects. Implant placement is possible after closure of OAC with chin graft, but coverage of graft with flap may lead to reduced vestibule, that have to be deepened before or during the implant placement. Transplant rejection, displacement of a graft into a sinus cavity, are potential serious complications of this technique, both consequencing a relapse $[6,12,20]$.

GTR technique is relatively simple and minimally invasive procedure that could be usefull for closure of $\mathrm{OAC}$ and OAF with large bony defects, denuded neighbouring teeth, and lack of soft tissue for local flaps. Occlusive properties of membranes used in GTR provides good conditions for repopularisation of surgical wound with undifferentiated cells, that later become well differentiated and highly specialised, providing recovery of the bone and periodontal tissues, instead of being replaced with fibrous tissue [13]. The membrane provides support for the blood clot in the defect so that it will organize, and will be replaced by bone and epithelialize on its oral surface $[13,16]$. It could be used in the cases with reduced depth of the buccal sulcus due to an unsuccessiful previous attempt to close OAF [16].

\section{CONCLUSION}

We treated our case of OAF with resorbable collagen membrane fixed wit pins in order to prevent its collapse into defect, and to preserve its position and barrier function. To prevent buccal sulcus reduction we decided not to cover whole membrane, rather to leave part of the membrane uncovered, repositioning buccal flap it to its original position. Exposure of the membrane in our case was treated by rinsing with $0,12 \%$ chlorhexidine-digluconate according to the instructions of Simion at al. [21]. Another advantage of treatment that we presented in this case, is bone regeneration and preservation of keratinised gingiva.

\section{REFERENCES}

1. Amaratunga NA. Oro-antral fistulae. A study of clinical, radiological and treatment aspects. Br J Oral Maxilofac Surg. 1986; 24:433-7.

2. Bluestone CD. The managment of oroantral fistulas. Otolaryngol Clin North Am. 1971; 4:179-91.

3. Anavi Y, Gal G, Silfen R, Calderon S, Tikva P. Palatal rotation-advancement flap for delayed repair of oroantral fistula: A retrospective evaluation of 63 cases. Oral Surg Oral Med oral Pathol Oral radiol Endod. 2003; 96:527-34.
4. Baumann A, Ewers R. Application of the buccal fat pad in oral reconstruction. J Oral Maxillofac Surg. 2000; 58:389-92.

5. Haanaes HR, Pedersen KN. Treatment of oroantral comunication. Int J Oral Surg. 1974; 3:124-32.

6. Haas R, Watzak G, Baron M, Tepper G, Mailath G. A preliminary study of monocortical bone grafts for oroantral fistula closure. Oral Surg Oral Med Oral Path Oral Radiol Endod. 2003; 96:263-6.

7. Killey HC, Kay LW. An analysis of 250 cases of oro-antral fistula treated by the buccal flap surgical procedure. Oral Surg Oral Med Oral Pathol. 1967; 24:726-39.

8. Proctor B. Bone graft closure of large or persistent oromaxillary fistula. Laryngoscope. 1969; 79:822-6.

9. Ziemba RB. Combined buccal and reverse palatal flap for closure of oro-antral fistula. J Oral Surg. 1972; 30:727-9.

10. Stajčić Z, Todorović Lj, Pešić V, Obradović O, Petrović V. Tissucol, gold plate, the buccal fat pad and the submucosal palatal island flap in closure of oroantral communication. Deutsch Zahnarztl Z. 1988; 43:133.

11. Waldrop TC, Semba SE. Closure of oroantral communication using guided tissue regeneration and an absorbable gelatin membrane. J Periodontol. 1993; 64(11):1061-6.

12. Thoma K, Pajarola FG, Gratz WK, Schmidlin RP. Bioabsorbable root analogue for closure of oroantral comunications after tooth extraction: A prospective case-cohort study. Oral Surg Oral Med Oral Path Oral Radiol Endod. 2006; 101:558-64.

13. Buser D, Dahlin C, Schenk R. Guided Bone Regeneration in Implant Dentistry. London: Quintessence Publishing Co, Ltd; 1994.

14. Del Junco R, Rappaport I, Allison G. Persistent oral antral fistulas. Arch Otolaryngol Head Neck Surg. 1988; 114:1315-6.

15. Wassmund $M$, Lidgas $G$, editors. Lehrbuch der praktischen Chirurgie des Mundes und der Kiefer. Leipzig, Germany: Meusser; 1935.

16. Guven O. A clinical study on oroantral fistulae. J Craniomaxillofac Surg. 1998; 26:267-71.

17. Kraut RA, Smith RV. Team approach for closure of oroantral and oronasal fistulas. Atlas Oral Maxillofacial Surg Clin N Am. 2000; 8:55-75.

18. Stajčić $Z$. The buccal fat pad in the closure of oro-antral communications:a study of 56 cases. J Craniomaxillofac Surg. 1992; 20:193-7.

19. Zide MF, Karas ND. Hydroxylapatite block closure of oroantral fistulas: report of cases. J Oral Maxillofac Surg. 1992; 50:71-5.

20. Yoshimasa K, Sano K, Nakamura M, Ogasawara T. Use of third molar transpalntation for closure of the oroantral communication after tooth extraction: a report of 2 cases. Oral Surg Oral Med Oral Pathol Oral Radiol Endod. 2003; 95:409-15.

21. Simion M, Trisi P, Maglione M, Piattelli A. Bacterial penetration in vitro through GTAM membrane with and without topical chlorhexidine application. A light and scaning electron microscopic study. J Clin Periodontol. 1995; 22(4):321-31.
Address for correspondence
Aleksa Marković
Clinic of Oral Surgery
School of Dentistry
Dr Subotića 4, 11000 Belgrade
Serbia
Email: maleksa@sbb.rs 


\title{
Zatvaranje oroantralne fistule resorptivnom kolagenom membranom - prikaz slučaja
}

\author{
Aleksa Marković, Snježana Čolić, Radojica Dražić, Ljiljana Stojčev, Bojan Gačić \\ Klinika za oralnu hirurgiju, Stomatološki fakultet, Univerzitet u Beogradu, Beograd, Srbija
}

\section{KRATAK SADRŽAJ}

Oroantralna fistula je patološka komunikacija između usne duplje i maksilarnog sinusa. Perzistentna fistula uvek izaziva hronični maksilarni sinuzitis. Cilj ovog rada je bio da se predstavi tehnika zatvaranja velike oroantralne fistule resorptivnom kolagenom membranom.

Ključne reči: oroantralna komunikacija; oroantralna fistula; kolagena membrana

\section{UVOD}

Oroantralna fistula (OAF) je patološka komunikacija između usne duplje i maksilarnog sinusa. Obično je lokalizovana na alveolarnom grebenu gornje vilice. Perzistentna OAF uvek izaziva hronični maksilarni sinuzitis $[1,2]$.

U literaturi su opisani razni hirurški postupci zatvaranja OAF, kao što su lokalni i udaljeni režnjevi, primena koštanih transplantata i aloplastičnih materijala [3-9]. Za zatvaranje se mogu koristiti i titanijumska i zlatna folija kao aloplastični materijali [10]. Želatinski film i neresorptivna politetrafluoroetilenska membrana (ePTFE) su bili prvi materijali kojima su zatvarane OAF metodom vođene regeneracije tkiva (VRT) [11]. Nedavno je prikazan bioapsorpcioni analog korena zuba za zatvaranje OAF [12]. Kolagene membrane koje se koriste u VRT usmeravaju rast mekog tkiva, podstičući tako zarastanje kosti [13].

Cilj rada je bio da se prikaže slučaj zatvaranja velike OAF primenom kolagene membrane Bio-Gide ${ }^{\circledast}$.

\section{PRIKAZ SLUČAJA}

Muškarac star 32 godine kod kojeg je dijagnostikovana OAF upućen je na Kliniku za oralnu hirurgiju Stomatološkog fakulteta Univerziteta u Beogradu. Na osnovu anamnestičkih podataka utvrđeno je da je nakon vađenja gornjeg desnog prvog molara u drugoj stomatološkoj ustanovi imao bolove 14 dana. Kliničkim pregledom ustanovljena je OAF i nakon rendgenskog pregleda dijagnostikovan hronični maksilarni sinuzitis desno (Slike 1 i 2). Pre operacije zahvaćeni sinus je ispiran kroz fistulu jednom dnevno fiziološkim rastvorom natrijum-hlorida i rastvorom gentamicina ( $80 \mathrm{mg}$ ) u trajanju od 14 dana, kako bi se smirila infekcija (Slika 3). Nije bilo gnoja i prirodni ostijum je bio prohodan.

Neposredno pre hirurškog lečenja pacijent je sedam dana primao amoksiklav u dozi od $1 \mathrm{~g}$ dva puta dnevno. U lokalnoj anesteziji lidokainom i dvopostotnim epinefrinom urađena je modifikovana Koldvel-Likova (Caldwell-Luc) operacija s oralnom antrostomijom. Nakon odizanja bukalnog režnja sinus je otvoren kroz očnjačku jamu (Slika 4). Posle ekscizije fistuloznog tkiva i kiretaže ektrakcione rane, otkriveno je oštećenje kosti veličine $15 \times 20 \mathrm{~mm}$ i ogoljen mezijalni koren susednog zuba 27 (Slika 5). Uklonjena je upaljena, degenerisana i polipoidna mukoza, a sinusna šupljina ispunjena jodoform-gazom. Uspostavljena je drenaža gazom kroz submukozalni otvor u vestibulumu sa suprotne strane (u regiji drugog sekutića) (Slika 6).

Resorptivna kolagenska membrana (Bio-Gide ${ }^{\varpi}$, Geistlich, Wolhusen, Switzerland) postavljena je preko koštanog oštećenja i učvršćena resorptivnim pinovima (Slika 7). Bukalni režanj je vraćen u prvobitni položaj bez zasecanja periosta i zašiven pojedinačnim šavovima (svileni konac 3-0). Membrana je izložena ka usnoj duplji $3 \mathrm{~mm}$ u bukopalatalnom i $10 \mathrm{~mm} \mathrm{u}$ meziodistalnom pravcu (Slika 8). Posle operacije pacijentu je preporučeno uzimanje nazalnog dekongestiva i sredstva za ispiranje usta $(0,12 \%$ hlorheksidin-diglukonata) dva puta dnevno do završetka epitelizacije. Drugog dana gaza je skraćena, četvrtog uklonjena, a sedmog dana skinuti su konci. Period oporavka pacijenta je protekao bez problema.

Oblast epitelizacije je praćena i proveravana perodontalnom sondom do kraja epitelizacije. Tokom prve nedelje polovina izložene membrane je bila pokrivena epitelom (Slika 9). Potpuno pokrivanje membrane je uočeno na kraju druge nedelje (Slika 10). Na kontrolnim rendgenskim snimcima tri meseca, šest meseci i 24 meseca posle operacije nije bilo promena u mukozi maksilarnog sinusa, a bila je očigledna osifikacija subantralnog dela alveolarnog grebena.

\section{DISKUSIJA}

Oroantralna komunikacija (OAK) je veoma česta komplikacija nakon vađenja gornjih molara ili kod postojanja periapikalnih lezija, cista ili tumora [14]. Smatra se da oko 50\% nelečenih OAK izaziva zapaljenjske promene u sluzokoži maksilarnog sinusa u prvih 48 sati, dok se oko $90 \%$ njih razvije u maksilarni sinuzitis dve nedelje posle stvaranja OAK [15]. Male OAK (manje od $2 \mathrm{~mm}$ u prečniku) obično spontano zarastaju [16] ukoliko ne postoji upala sinusa, dok je veće potrebno hirurški lečiti. Zatvaranje OAK u prva 24 sata je obavezno; u suprotnom, kao posledica može nastati OAF [17]. Postojanje parodontalno ugroženog zuba neposredno uz OAF je dodatni problem za uspešno zarastanje većine režnjeva mekog tkiva.

Za zatvaranje OAF se obično koriste bukalni ili palatalni režnjevi ili njihova kombinacija. Bukalni režnjevi se najčešće koriste za zatvaranje OAF, ali tenzija režnja $[16,17]$, postoperacioni hematom $[4,5,9]$ i smanjenje dubine bukalnog sulkusa [18, 19] mogu ugroziti uspešno zatvaranje OAF ili izradu adekvatne protetičke nadoknade. Štaviše, gubitak kosti koji se obično 
vezuje za OAF ponekad može da dovede do dehiscencije i sledstvenog recidiva. Takvo oštećenje kosti koje pokriva samo bukalni režanj zarasta fibrozno, što onemogućava postavljanje implantata bez dodatnog presađivanja slobodnog koštanog transplantata. Palatalni režnjevi stvaraju ogoljenu oblast koja zarasta sekundarno. Ona može biti praćena bolom i traje duže uz moguće stvaranje ožiljaka $[3,10,17]$.

Kod većeg oštećenja kosti zatvaranje OAF može biti i masnim jastučetom obraza. Prednost ovoga načina zatvaranja u odnosu na bukalne režnjeve je u tome što se ne ometa dubina bukalnog sulkusa. Može se javiti rizik od invaginacije masnog tkiva, nepredvidljivog sekundarnog zarastanja, infekcije, nekroze, fibroze, skupljanja i retrakcije [3]. Kao i u slučajevima bukalnih režnjeva, ne dolazi do regeneracije oštećenje kosti.

Proktor (Proctor) [8] je 1969. opisao zatvaranje OAF koštanim transplantatom s kuka koje je indikovano kod OAF s velikim oštećenjima kosti. To je atraktivna tehnika za povećanje subantralne kosti i postavljanje implantata, ali je zbog morbiditeta njena primena ograničena.

Kod umereno velikih oštećenja kosti za zatvaranje OAK se mogu koristiti monokortikalni transplantati sa brade [6]. Posle zatvaranja OAK ovim transplantatom, njegovo pokrivanje režnjem može dovesti do smanjenja vestibuluma, koji mora da se produbi pre ili tokom postavljanja implantata. Odbacivanje transplantata, odnosno njegovo pogrešno postavljanje u sinusnu šupljinu potencijalne su komplikacije ove tehnike jer može doći do recidiva $[6,12,20]$.

Tehnika VRT je relativno jednostavan i minimalno invazivan postupak za zatvaranje OAK i OAF sa velikim oštećenjima kosti, ogoljenim okolnim zubima i nedostatkom mekog tkiva za lokalne režnjeve. Okluzivna svojstva membrana koje se koriste u VRT obezbeđuju dobre uslove za repopularizaciju hirurške rane neizdiferenciranim ćelijama, koje kasnije obezbeđuju obnavljanje kosti i periodontalnih tkiva odgovarajućim tkivima umesto zamene fibroznim tkivom [13]. Membrana obezbeđuje podršku krvnom ugrušku u oštećenju kosti, koji se bolje organizuje i zamenjuje koštanim tkivom uz epitelizaciju i zatvaranje rane na površini $[13,16]$. VRT se može primeniti kada je smanjena dubina bukalnog sulkusa usled prethodnog neuspešnog pokušaja zatvaranja OAF [16].

\section{ZAKLJUČAK}

Pacijent sa OAF prikazan u ovom radu lečen je resorptivnom kolagenom membranom fiksiranom pinovima, kako bi se sprečilo njeno urušavanje u oštećenje kosti i očuvala njena pozicija i funkcija barijere. Da bi se sprečilo smanjenje bukalnog sulkusa, odlučeno je da se ne prekriva cela membrana, već da jedan njen deo ostane nepokriven, postavljajući bukalni režanj na njegovu prvobitnu poziciju. Membrana je u ovom slučaju ispirana hlorheksidin-diglukonatom od $0,12 \%$ prema uputstvima Simiona (Simion) i saradnika [21]. Još jedna prednost ove tehnike je i očuvanje keratinizovane gingive, što može biti značajno prilikom ugradnje endosealnog implantata u regiji OAF. 